\title{
PEMBERDAYAAN PEREMPUAN DAN PERBAIKAN MANAJEMEN USAHA BAGI PENENUN SONGKET
}

\author{
Berlianti $^{1)}$, Matias Siagian ${ }^{2}$ \\ 1) Prodi Ilmu Kesejahterahan Sosial FISIP USU \\ Email: berlianti_fisipusu@yahoo.co.id \\ 2) Prodi Ilmu Kesejāhterahan Sosial FISIP USU \\ Email: matiassiagian@gmail.com
}

\begin{abstract}
Abstrak
Dalam rangka meningkatkan kesejahteraan masyarakat, industri kecil memiliki peran yang sangat strategis mengingat berbagai potensi yang dimilikinya. Potensi tersebut antara lain mencakup jumlah dan penyebarannya, penyerapan tenaga kerja, penggunaan bahan baku lokal, keberadaannya di semua sektor ekonomi dan ketahanannya terhadap krisis. Industri kecil bisa menjadi tempat aktualisasi diri individu-individu kreatif, yang bisa melahirkan gagasan-gagasan kreatif bernilai ekonomi tinggi. Banyak pekerja wanita yang terlibat menjadi pekerja kreatif, misalnya disubsektor kerajinan, fashion, desain dan seni pertunjukan. Ini bisa menjadi ajang penyetaraan gender karena dalam industri kecil, pekerja laki-laki dan perempuan memiliki kesempatan yang sama untuk berkembang, selama mereka kreatif dan inovatif.Sehubungan dengan hal tersebut, maka dirasa perlu diberikan pelatihan peningkatan ketrampilan pembuatan songket kepada pengrajin songket agar mampu menghasilkan songket yang berkualitas tinggi sesuai dengan keinginan pasar secara efisien dan efektif tanpa mengurangi nilai budaya yang terkandung dalam songket. Selain itu meningkatkan ketrampilan dalam strategi pemasaran agar memiliki kemampuan dalam memasarkan songket yang di produksi, sehingga mampu menciptakan dan memiliki banyak jaringan pemasaran. Perlunya diberikan pelatihan yang memampukan pengrajin songket menghitung total pendapatan penjualan dan total biaya sehingga mampu mengetahui berapa laba yang diperoleh per satu potong songket. Diharapkan setelah pendampingan, para mitra menjadi lebih meningkat pengetahuannya, mampu mengaplikasikan pengetahuan tersebut dalam pekerjaan sehari-harinya dan menularkan pengetahuan tersebut kepada pengrajin songket yang lain. Dengan demikian semua pengrajin songket akan lebih berkembang, menjadi semakin mandiri secara ekonomis, terjadi peningkatan pendapatan, pengrajin songket menjadi lebih produktif serta semakin optimis dalam berusaha songket sehingga perekonomian bangsa akan menjadi lebih baik.
\end{abstract}

\section{Kata Kunci: Industri Kecil, Pengrajin Songket, Strategi Pemasaran, Peningkatan Pendapatan}

\section{PENDAHULUAN}

Peranan industri kecil pada penyerapan tenaga kerja biasanya cukup signifikan. Di Indonesia, industri kecil rata-rata mampu menyerap tenaga kerja sekitar 5,4 juta jiwa per tahun atau setara dengan $5,8 \%$ dari seluruh tenaga kerja. Ekonomi industri kecil juga memiliki peranan penting untuk mengikat manusia-manusia pelaku industri kecil ke dalam kerja sama sosial. Penciptaan komunitas kreatif di mana para anggotanya saling berinteraksi dan bertukar gagasan kreatif akan menyatukan mereka ke dalam suatu hubungan sosial. Komunitas kecil akan berinteraksi layaknya interaksi di dalam sebuah organisasi, akan ada kerja sama, akan ada konflik, dan akan ada penyesuaian dan adaptasi diantara para anggotanya. Proses-proses ini akan menguatkan ikatan di antara pelaku dan selanjutnya akan membentuk toleransi sosial dan modal social di masyarakat.

Kondisi industri kecil yang ada di Indonesia saat ini terdapat sebanyak 42 juta usaha mikro dan kecil dan $80 \%$ diantaranya bergerak dibidang pertanian. Potensi industri kecil yang sebanyak itu, tentu saja memberikan dampak bagi produk domestic bruto (PDB) yang tidak sedikit bagi daerah dan pusat serta penyerapan tenaga kerja yang besar karena sektor industri kecil didominasi padat karya atau home industri.

Dalam rangka meningkatkan kesejahteraan masyarakat, industri kecil memiliki peran yang sangat strategis 
Berlianti. et.al. Pemberdayaan Perempuan Dan Perbaikan Manajemen Usaha Bagi Penenun Songket

mengingat berbagai potensi yang dimilikinya. Potensi tersebut antara lain mencakup jumlah dan penyebarannya, penyerapan tenaga kerja, penggunaan bahan baku lokal, keberadaannya di semua sektor ekonomi dan ketahanannya terhadap krisis. Pentingnya industri kecil khususnya di negara Indonesia dimana jumlah tenaga kerja berpendidikan rendah dan aneka sumber alam sangat berlimpah, kapital terbatas, pembangunan pedesaan masih terbelakang dan distribusi pendapatan tidak merata, sangat erat hubungannya dengan sifat umum kelompok industri kecil.

Industri kecil bisa menjadi tempat aktualisasi diri individu-individu kreatif, yang bisa melahirkan gagasan-gagasan kreatif bernilai ekonomi tinggi. Banyak pekerja wanita yang terlibat menjadi pekerja kreatif, misalnya disubsektor kerajinan, fashion, desain dan seni pertunjukan. Ini bisa menjadi ajang penyetaraan gender karena dalam industri kecil, pekerja laki-laki dan perempuan memiliki kesempatan yang sama untuk berkembang, selama mereka kreatif dan inovatif.

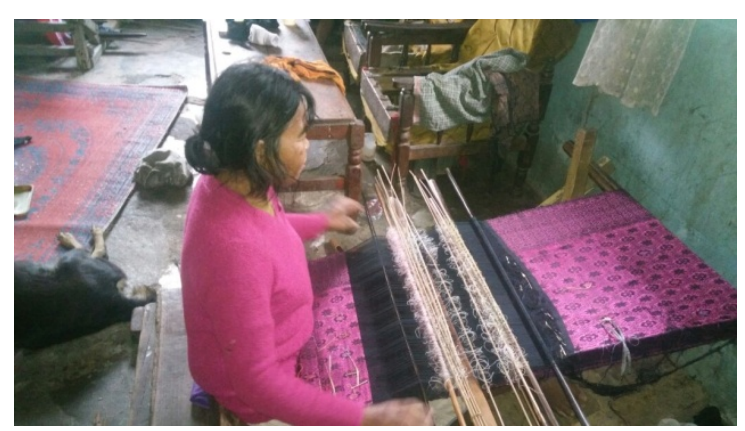

Gambar 1. perempuan batak sedang menenun songket

Salah satu kearifan lokal orang Batak adalah bertenun yang menghasilkan warisan budaya tenun tangan bernama songket (mandar). Keberadaan songket sangat erat kaitannya dengan kehidupan masyarakat adat Batak hingga saat ini. Selain digunakan dalam upacara adat, keberadaan songket ini juga dikenal sebagai salah satu ciri khas budaya Batak, dan saat ini banyak dijadikan souvenir.
Kaum perempuan yang menjadi pengrajin songket menjadikan kerajinan tenun ini sebagai mata pencaharian utama dan juga sebagai pekerjaan sampingan. Pengrajin songket tersebut masih menggunakan alat-alat tradisional dan membutuhkan waktu produksi yang lebih lama sehingga terkesan kurang efisien dalam pengerjaannya.

Yuniarti dan Haryanto (2005) menyatakan pendapatan para pekerja wanita pada industri sandang mempunyai kontribusi yang signifikan terhadap peningkatan pendapatan keluarga. Kontribusi perempuan dapat dikatakan sebagai katup pengaman (safety valve) atau penopang bagi rumah tangga miskin untuk memnuhi kebutuhan dasar sehari-hari. Beberapa hasil penelitian menunjukkan peran serta wanita dalam berbagai industri di beberapa daerah cukup besar dan menentukan. Salah satu keterlibatan perempuan dalam dunia kerja yaitu banyaknya perempuan daerah yang menjadi pengrajin.

Untuk meningkatkan penjualan, para perajin industri kecil perlu memperhatikan aspek pemasaran. Pemasaran produk secara langsung ataupun lewat perantara sebaiknya dioptimalkan. Upaya sebagian kecil perajin industri kecil yang sudah mempromosikan kreativitas mereka lewat jaringan internet perlu diikuti oleh perajin industri kecil yang lain. Dalam hal ini perajin industri kecil dapat bekerja sama dalam paguyuban untuk mengusahakan bantuan dari pemerintah ataupun lembagalembaga swasta yang concern terhadap perkembangan industri kecil agar memberikan dukungan dalam bentuk fasilitas, pelatihan Teknologi Informasi (TI) ataupun pendampingan. Dengan demikian diharapkan cakupan promosi lebih luas dan efektif sehingga usaha para perajin dapat lebih berkembang.

Demikian halnya di Desa Hutabarat Partali, sektor informal yakni kerajinan tenun songket menjadi alternatip bagi perempuan dan telah banyak membantu 
perekonomian keluarga di desa ini, khususnya golongan menengah ke bawah. Sehubungan dengan latar belakang di atas, maka tim pengusul merasa tertarik untuk melakukan pengabdian pada masyarakat khususnya perempuan pengrajin songket yang diberi judul "Pemberdayaan Perempuan Dan Perbaikan Manajemen Usaha Bagi Penenun Songket".

\section{PERMASALAHAN MITRA}

a. Rendahnya kapasitas perempuan pengrajin songket dalam memahami persoalan-persoalan yang mereka hadapi.

b. Rendahnya pengetahuan dan wawasan perempuan pengrajin songket dalam melihat peluang pemasaran songket. Perempuan pengrajin songket melihat hanya terbatas di pasar lokal.

c. Rendahnya keterampilan mitra dalam memproduksi songket sehingga kurang mampu bersaing dari sisi kualitas, variasi motif dan perpaduan warna.

d. Rendahnya pengetahuan perempuan pengrajin songket dalam memproduksi secara efektif dan efisien melalui perhitungan laba dan analisis biaya yang lebih baik, sehingga mampu meningkatkan pendapatan perempuan pengrajin songket.

\subsection{Solusi yang Ditawarkan}

Untuk meningkatkan daya saing pelaku home industri pembuatan songket Tarutung yang ada di Kabupaten Tapanuli Utara, maka dirasa perlu melakukan pengabdian kepada perempuan pengrajin songket dengan cara :

1. Ceramah dan diskusi, untuk mengetahui lebih jelas permasalahan dasar pengrajin songket, sehingga bisa diberikan solusi masalah.

2. Mengadakan sosialisasi arti penting home industri kerajinan kain songket. Disamping melestarikan budaya lokal, juga memampukan perempuan di Kabupaten Tapanuli Utara menjadi mandiri secara ekonomis. Meyakinkan pengrajin bahwa kain songket tetap akan diminati bila diproduksi sesuai dengan selera pasar dan dengan proses produksi yang efektif dan efisien sehingga mampu memperluas pasar.

3. Melaksanakan pelatihan dengan mengundang pakar penenun songket agar pengrajin memiliki kemampuan memproduksi songket atau menenun songket yang berkualitas baik dalam variasi motif dan juga perpaduan warna agar mampu menciptakan dan memperluas jaringan pasar.

4. Melatih pengrajin songket agar mampu memproduksi secara efektif dan efisien melalui perhitungan laba dan analisis biaya yang lebih baik, sehingga mampu meningkatkan pendapatan perempuan pengrajin songket.

\section{METODE}

\subsection{Rencana Kegiatan}

Rencana kegiatan yang akan dilakukan untuk pemecahan masalah adalah dengan tahapan sebagai berikut :

1. Sosialisasi

Sosialisasi dilakukan kepada perempuan pengrajin songket di Kabupaten Tapanuli Utara. Materi sosialisasi adalah keberadaan dan makna songket bagi masyarakat Batak maupun masyarakat Tapanuli Utara, pentingnya menjaga dan melestarikan warisan budaya lokal, peningkatan pendapatan dan kesejahteraan masyarakat Tapanuli Utara melalui usaha kerajinan songket.

2. Ceramah dan diskusi

Setelah kegiatan sosialisasi dilakukan tim pengabdian akan melakukan ceramah dan diskusi tentang rencana kegiatan. Berdasarkan ceramah dan diskusi ini tim pengabdian akan dapat mengetahui ketertarikan masyarakat terhadap kegiatan pengabdian. Selain itu dapat membangun motivasi tinggi untuk meningkatkan keterampilan.

3. Rekrutmen

Rekrutmen adalah bentuk pernyataan selain mitra yang bersedia untuk 
Berlianti. et.al. Pemberdayaan Perempuan Dan Perbaikan Manajemen Usaha Bagi Penenun Songket

\begin{tabular}{lccl}
\hline mengikuti & kegiatan pengabdian. & menanyakan keuntungan dan \\
Pengrajin & songket yang bersedia & hambatan yang dijumpai setelah \\
selanjutnya & dibimbing & untuk & kegiatan pelatihan selesai dilakukan. \\
mengikuti & jadwal & kegiatan &
\end{tabular}

mengikuti jadwal kegiatan pengabdian, sedangkan bagi pengrajin yang tidak bersedia tentunya tidak dikutsertakan lagi dalam kegiatan pengabdian selanjutnya. Kegiatan rekrutmen ini bersifat sukarela tanpa ada paksaan ataupun tekanan dari siapapun.

4. Pelatihan Penenunan Songket

Pelatihan dilakukan dengan mengundang orang yang memang sudah diakui keahliannya dalam membuat songket. Diperkirakan ada sebanyak 2-3 orang yang akan menjadi pelatih dalam pembuatan songket ini. Dalam pelatihan ini maka tim pengabdian akan memfasillitasi dan menyediakan semua bahan-bahan dan peralatan yang diperlukan dalam pembuatan songket tersebut. Pelatihan ini diharapkan akan meningkatkan keterampilan para mitra sehingga hampir sama dengan keterampilan tutornya.

5. Pelatihan strategi pemasaran

Dalam pelatihan ini tim pengabdian akan mengajarkan bagaimana cara memasarkan produk songket ini serta membangun jaringan di kabupaten dan kota serta propinsi yang ada di Indonesia. Selain itu juga memberi pelatihan agar memiliki mental kewirausahaan serta mampu dan percaya diri dalam mengembangkan usaha kerajinan songket.

6. Evaluasi

Evaluasi akan dilakukan selama pelaksanaan kegiatan pengabdian di Tapanuli Utara yang meliputi pengamatan keterampilan dalam pembuatan songket dan pengamatan dalam strategi pemasaran. Selain itu juga evaluasi akan dilakukan meskipun kegiatan pelatihan sudah selesai, yaitu dengan bertelepon menanyakan kemajuan usaha songket selama ini dan juga dengan mengunjungi kembali pengrajin songket di Tapanuli Utara

\section{HASIL DAN PEMBAHASAN}

Pelaksanaan kegiatan pengabdian dilaksanakan mulai bulan September 2016. Diawali dengan kegiatan diskusi kelompok yang membahas permasalahanpermasalahan mitra. Tujuan diskusi dilakukan untuk mencari dan mengenali permasalahan yang dialami mitra pengabdian.

Tindak lanjut dari diskusi yang telah dilakukan adalah meningkatkan pengetahuan mitra mengenai masalah manajemen usaha, perhitungan harga pokok produksi dan pelatihan peningkatan ketrampilan. Permasalahan-permasalahan tersebut yang diyakini telah membuat operasional usaha mitra berjalan kurang efektif.

Kegiatan penyuluhan disepakati dilaksanakan di lokasi mitra. Metode penyuluhan dilakukan dengan metode ceramah kepada semua anggota kelompok mitra yang dilakukan secara berkelompok. Selanjutnya dilakukan pemberian hibah bantuan berupa alat serta bahan penunjang usaha mitra.

Peningkatan ketrampilan mitra dalam menenun dan membuat motif baru dilakukan dengan memberikan gambargambar serta mendatangkan pelatih. Selama dua bulan 2 kali dalam seminggu pelatihan untuk meningkatkan ketrampilan ini dilakukan. Mengenai jadwal dan tempat pelatihan diserahkan kepada kesepakatan antara mitra dengan pelatih yang diundang. Hal ini bertujuan agar pelatihan dapat berjalan lebih efektif dan bermanfaat maksimal.

Kegiatan pengabdian dilanjutkan terus dengan pendampingan kepada mitra pengabdian secara rutin dan kontiniu. Mitra dapat secara aktif menghubungi dan 
berdiskusi dengan tim pengabdian menggunakan teknologi yang tersedia. Selain itu, untuk meningkatkan interaksi antara tim pengabdian dan mitra pengabdian, maka tim pengabdian juga menghubungi dan berkunjung ke tempat usaha mitra. Kunjungan ke tempat mitra pengabdian dilakukan dengan tujuan agar mitra dapat lebih efektif dan efisien dalam melaksanakan proses produksi usaha menjahit mereka.

\section{KESIMPULAN}

Berdasarkan pengabdian ini kesimpulan yang dapat diambil adalah:

1. Kegiatan pengabdian berlangsung dengan baik dan memperoleh sambutan yang besar dari mitra.

2. Terjadi perubahan perilaku mitra, dimana mitrasudah mulai mencatat semuapengeluaran dan pemasukan usaha tenun songketnya.

\section{UCAPAN TERIMA KASIH}

Peneliti mengucapkan terima kasih atas support dana dari BPPTN Universitas Sumatera Utara tahun 2018 sehingga pengabdian kepada masyarakat ini dapat berjalan.

\section{DAFTAR PUSTAKA}

Alma, Buchari. (2008). Manajemen Pemasaran dan Pemasaran Jasa. Penerbit Alfabeta, Bandung

Brigham, Eugene F and Joel F Houston, 2004, Fundamentals of Financial Management, 10e, International Student Edition, Thomson Learning.

Cravens, David W. (2009). Strategic Marketing. Seventh Edition. Boston: Irwin McGraw-Hill

Ferdinand, Augusty. (2002), Marketing Strategy Making: Proses dan Agenda Penelitian, Journal Sains Pemasaran Indonesia. Vol 1, No.1, Mei, p.1-22

Hisrich\& Peters, 2002, Entrepreneurship, Fifth Edition.New York:McGraw-Hill Higher Education
Kotler, Phillip, 2008, Marketing Management - The Millenium Edition, Prentice Hall.

Salvatore, Dominick. 2005. Managerial Economics. Edisi Kelima. Jilid Pertama.Jakarta: Salemba Empat.

Suryana, 2006, Kewirausahaan Pedoman Praktis: Kiat dan Proses Menuju Sukses, Jakarta:Salemba Empat

Sutojo, Siswanto, 2003, Manajemen Penjualan yang Efektif, PT. Darma Mulia Pustaka

Van Horne, James and John M. Machowics, JR, 2001, Pinciple of Financial Management, Prentice Hall. 